\title{
Long-term variations in primary production in a eutrophic sub-estuary. II. Interannual variations and modeling
}

\author{
Charles L. Gallegos* \\ Smithsonian Environmental Research Center, PO Box 28, Edgewater, Maryland 21037, USA
}

\begin{abstract}
A 19 yr time series of annual primary production in the eutrophic Rhode River subestuary of the Chesapeake Bay in Maryland (USA) was analyzed in relation to climatological and ecological factors. The objectives of this work were to understand factors controlling interannual variations in primary production in a eutrophic estuary and develop a model for tracking future variations in production, in the absence of direct measurements of photosynthetic carbon uptake. Annual production $\left(P_{\mathrm{A}}\right)$ averaged 328 (range 152 to 612 ) $\mathrm{g} \mathrm{C} \mathrm{m}^{-2} \mathrm{yr}^{-1}$. Interannual variability was statistically significant, but there was no significant linear trend or significant non-random variations over the available $19 \mathrm{yr}$. Climatological indices based on North Atlantic Oscillation or flow of the Susquehanna River, the principal N source to the upper Chesapeake Bay, were not significant predictors of $P_{\mathrm{A}}$. A classification of years based on magnitude of the spring dinoflagellate bloom and timing of nitrate depletion was a significant predictor of $P_{\mathrm{A}}$. Phytoplankton biomass, $B$, and the light saturated photosynthetic rate normalized to chlorophyll, $P_{\max }^{B}$, were of similar magnitude in their influence on the variance in $P_{\mathrm{A}}$. The high degree of variability in $P_{\max }^{B}$ weakened efforts to model both daily and annual production from measurements of chlorophyll and light attenuation. Between 4 and $15 \mathrm{yr}$ of measurements of chlorophyll and light attenuation would be needed to detect a change in trophic status of the sub-estuary, depending on the level of reduction achieved in $P_{\mathrm{A}}$. Average daily production would have to be reduced below $1052 \mathrm{mg} \mathrm{C} \mathrm{m}^{-2} \mathrm{~d}^{-1}$ to achieve mesotrophic status.
\end{abstract}

KEY WORDS: Phytoplankton · Primary production · Annual production $\cdot$ Estuary $\cdot$ Interannual variability $\cdot$ Rhode River

\section{INTRODUCTION}

Coastal systems worldwide have undergone anthropogenic eutrophication, defined as an increase in the rate of supply of organic matter (Nixon 1995) due to nutrient inputs from human activity (Richardson \& Jørgensen 1996). Much has been learned in recent decades about the factors governing sensitivity of different estuarine systems to nutrient loading and its effects on the ecological and biogeochemical functioning of estuaries (Cloern 2001). Indeed, total ecosystem production may actually decline under eutrophication due to the loss of benthic primary producers (microalgae, macroalgae, seagrasses) as a result of increases in pelagic planktonic production (Krause-Jensen et al. 2012). Additionally, our expectations for the recovery of systems following reduction of nutrient loadings has been tempered by the understanding that baselines of phytoplankton biomass may have shifted due to climate change (Duarte et al. 2009). While the volumetric rate of primary productivity may be a superior indicator of trophic status compared with the areal rate (Smith 2007), the rate of supply of organic matter by the production of phyto- 
plankton remains at the core of our growing conceptual understanding of coastal eutrophication (Cloern 2001), and reversal of enhanced rates of planktonic carbon input remains indispensable to restoration of unimpaired estuarine functioning.

Implicit in Nixon's (1995) definition of eutrophication is a long, though unspecified, time perspective. In the years since that definition, some jurisdictions have begun to curtail nutrient overenrichment, leading Nixon (2009) to propose the term 'oligotrophication' to describe the reduction in the rate of organic carbon input to the system. While the basic criteria for trophic classification were given in terms of annual production, detection of an increase or decrease in primary production must be statistically evaluated in the context of normal interannual variability. Nutrient input in estuaries involves an interaction between climatic forcing and human activities in the watershed and airshed (Howarth et al. 1996). Over long time periods, estuaries are also affected by other documented drivers, such as water diversions, changing sediment supplies and turbidity, disturbance by introduced species, dredging, etc., that may affect phytoplankton production by various direct and indirect processes (Cloern \& Jassby 2012). Detecting a management-initiated change within the normal year-to-year fluctuations in primary production affected by multiple changing drivers is expected to be challenging.

Efforts to reverse anthropogenic eutrophication of coastal systems are aimed at reduction of phytoplankton biomass by limitation of nutrient inputs by humans (Krause-Jensen et al. 2012). Our expectations of the efficacy of such efforts must be informed by an understanding of the relative importance of phytoplankton biomass, physiological parameters, environmental factors, and their covariances in determining the magnitude and variance of annual production by phytoplankton. Additionally, there is a need for a means to determine levels of phytoplankton biomass that will achieve specified trophic status (e.g. Harding et al. 2014), and how that level depends on physiological and environmental parameters. Accordingly, the objectives of this work were to understand factors controlling interannual variations in primary production in a eutrophic subestuary, and to examine the capability of tracking future variations by modeling, in the absence of direct measurements of photosynthetic carbon uptake. A $19 \mathrm{yr}$ time series of annual production in the Rhode River (Maryland, USA) sub-estuary of Chesapeake Bay was analyzed in terms of climatic forcing and year-to-year variations in phytoplankton bio- mass and physiological parameters. Variations in physiological parameters and covariation with biomass were found to be important, and place constraints on the skill of models designed to track changes in annual production in the absence of continuing production measurements. Application of the model to assess future trends is critically dependent on the continuation of monitoring activities (Andersen et al. 2011).

\section{MATERIALS AND METHODS}

\section{Study site}

The Rhode River ( $38^{\circ} 52^{\prime} \mathrm{N}, 76^{\circ} 31^{\prime} \mathrm{W}$ ) is a shallow, eutrophic tributary on the western shore in the mesohaline zone of the Chesapeake Bay in Maryland (USA). Salinity averages 9.6 and varies from 0 at the head following runoff events to nearly 20 at the mouth in dry years. Depth of the Rhode River varies from $4 \mathrm{~m}$ at the mouth to $<1 \mathrm{~m}$ in an area of broad subtidal mudflats near the head and averages $2 \mathrm{~m}$. The sub-estuary has been the subject of long term studies of nutrients and chlorophyll (Jordan et al. 1991a,b), phytoplankton blooms, species composition, photosynthetic parameters (Gallegos 1992, 2012, Gallegos et al. 1997, 2010), and fish and invertebrates (Hines et al. 1990). The sub-estuary is usually well mixed vertically (Seliger \& Loftus 1974), though subsurface peaks in the concentration of chlorophyll a ( $\mathrm{chl}$ a) are sometimes present near the Secchi depth associated with dinoflagellate blooms (Gallegos et al. 1990, Gallegos 1992).

\section{Field and laboratory measurements}

Measurements made on cruises of the Rhode River were described in detail by Gallegos (2012) and a brief account is given in a companion paper (Gallegos 2014, this volume). Six stations were sampled at weekly to bi-weekly intervals from 1990 to 2009 . Sampling period usually ranged from early March through mid-December depending on ice and weather conditions or availability of boats, though in some years sampling continued all year, especially early in the series. Stations are designated by their distance from the mouth $(\mathrm{km}$, positive up estuary). In situ measurements consisted of depth profiles of temperature, salinity, dissolved oxygen, and downwelling cosine-corrected photosynthetically active radiation (PAR, 400-700 nm). Sample collection, cal- 
culation of diffuse attenuation coefficients for PAR $\left(K_{\mathrm{d}}\right)$, and measurement of photosynthesis-irradiance $(P-E)$ parameters were described previously (Gallegos 2012, 2014).

\section{Calculation of primary production}

The integrated rate of daily primary production over the depth of the water column, $H_{\text {, was calcu- }}$ lated as described previously (Gallegos 2014); sufficient detail is given here to introduce the notation.

The rate of photosynthesis normalized to pigment biomass, $P^{B}$, as a function of available light, $E$, was represented by a hyperbolic tangent function (Jassby \& Platt 1976):

$$
P^{B}(E)=P_{\max }^{B} \tanh \left(\frac{\alpha^{B} E}{P_{\max }^{B}}\right)+R^{B}
$$

where $P_{\max }^{B}=$ the maximal rate of ${ }^{14} \mathrm{C}$ uptake at light saturation, $\alpha^{B}=$ the slope of the linear portion of the curve at low light intensities, and $R^{B}=$ the zero-light intercept, is retained to prevent bias in the fitting of $\alpha^{B}$.

Platt \& Sathyendranath (1993) showed that the integral of photosynthesis over the day, $P_{H, T}$ in a water column of arbitrary depth could be calculated as:

$$
P_{H, T}=A \cdot F_{0, H}\left(E_{*}^{\mathrm{m}}\right)
$$

where the scale factor, $A$, is given by:

$$
A=\frac{B P_{\max }^{B} D}{K_{\mathrm{d}}}
$$

$B=$ phytoplankton biomass as chl a (here assumed uniform with depth), $D=$ photoperiod, $E_{*}^{\mathrm{m}}$ is the maximal noontime incident solar irradiance, $E_{0}{ }^{\mathrm{m}}$, divided by the photoadaptation parameter, $E_{\mathrm{k}}=P_{\max }^{B} / \alpha^{B}$ separating light-limiting from light-saturating irradiances, and $F$ is a dimensionless integral of the photosynthesis vs. depth profile (Behrenfeld \& Falkowski 1997). The function $F$ is given by an infinite series that is accurately approximated by a polynomial expansion of $E_{*}^{\mathrm{m}}$ with coefficients given by Platt \& Sathyendranath (1993). For an optically shallow water column, the function $F$ is calculated by first evaluating the polynomial in $E_{*}^{\mathrm{m}}$ from the surface to $z=\infty$, where $z$ is the geometric depth below the surface, then subtracting the evaluation of $F$ from $z=H$ to $\infty$, that is:

$$
F_{0, H}\left(E_{*}^{\mathrm{m}}\right)=F_{0, \infty}\left(E_{*}^{\mathrm{m}}\right)-F_{H, \infty}\left(E_{*}^{\mathrm{m}} \mathrm{e}^{-K_{\mathrm{d}} H}\right)
$$

To perform the integration over depth and time, it was necessary to use an exponential function for the
$P$-E relationship (Platt et al. 1990). $E_{\mathrm{k}}$ estimated from parameters in Eq. (1) was multiplied by a factor of 0.759 to account for the differences in light saturation between Eq. (1) and the exponential P-E relationship used to derive Eq. (2) (Gallegos 2014). An empirically derived factor, $S\left(Z_{\mathrm{OD}}\right)$, to correct for the use of cosine corrected rather than scalar irradiance, and for the spectral mismatch between incubation light source and the in situ spectrum was found to be dependent on optical depth, $Z_{\mathrm{OD}}=K_{\mathrm{d}} H_{\text {, and given by (Gallegos }}$ 2014, Supplement):

$$
S\left(Z_{\mathrm{OD}}\right)=\frac{1}{1+\left(0.0647 Z_{\mathrm{OD}}-0.0307\right)}
$$

$\mathrm{S}\left(Z_{\mathrm{OD}}\right)$ was generally $<1$ and multiplies the right hand side of Eq. (2).

Two sets of calculated values of daily production, $P_{H, T}$, were used in the analysis of annual production. All available sampling dates and incident irradiance measurements were used for examination of interannual variations in $P_{H, T}$. For analysis of annual integrated production, $P_{\mathrm{A}}$, restrictions were applied to the data to avoid introducing spurious interannual variations as artifacts of data availability. Calculation of $P_{\mathrm{A}}$ was commenced with the first sampling date in April to adjust for year-to-year differences in first date of sampling. Based on 4 yr (1990-1993) in which sampling commenced in January, the omitted production ranged from $2.9 \%$ to $16 \%$ and averaged $8.1 \%$ of the full yearly total. Due to funding limitations, sampling commenced too late in 2007 for calculation of annual production in that year. In some years, there were large gaps in the availability of incident irradiance due to sensor or recorder failure. Therefore, the model of Gregg \& Carder (1990) was used to calculate $E_{0}{ }^{\mathrm{m}}$ in all years, assuming clear-sky conditions. In $2 \mathrm{yr}$ in which incident irradiance records were available for all sampling dates, the clearsky assumption led to overestimates varying (with station) from $2.7 \%$ to $4.1 \%$ in 2008 and $5.5 \%$ to $9.5 \%$ in 2009. These excluded variations were small compared with calculated variations (see 'Results' section 'Annual production'). Annual primary production, $P_{\mathrm{A}}$, was calculated by trapezoidal rule integration of the calculated $P_{H, T}$ for each year and station.

\section{Data analysis}

Factors controlling the interannual variability in primary production were examined by General Linear Model (GLM). The analysis was carried out at 2 scales. Firstly, GLM was performed on $P_{\mathrm{A}}$ as the 
dependent variable, using as predictors several measures of climatology and spring bloom phenology, both categorical and numerical; secondly, GLM was performed on $P_{H, T}$, focusing on the annual factor of the GLM analysis as described below. Prior analyses have shown that nutrient delivery to Chesapeake Bay and phytoplankton biomass are strongly linked to flow of the Susquehanna River (Kimmel et al. (2009), and have been shown to be modestly correlated with a climate index, the North Atlantic Oscillation (NAO, Prasad et al. 2010). Climatological variables examined were, therefore (1) annual flow (AQ) and (2) spring flow (SQ, March through May) of the Susquehanna River categorized as wet (W), normal (N), or dry (D) following Kimmel et al. (2009), and (3) winter averaged NAO index as a continuous variable (ftp://ftp.cpc.ncep.noaa.gov/wd52dg/data/indices/ tele_index.nh). Years with cumulative flow over the period (annual or spring) $>75$ th percentile were classified as $W$, cumulative flow $<25$ th percentile as D, and others as N (Kimmel et al. 2009). Years were classified according to spring bloom category (BLC) based on peak chlorophyll concentration and timing of nitrate depletion at Stn 3.8 according to criteria in Gallegos et al. (1997): extraordinary bloom (EB) = peak chlorophyll concentration $>120 \mathrm{mg} \mathrm{m}^{-3}$ prior to 30 May; average bloom $(\mathrm{AB})=$ peak chlorophyll concentration between 70 and $110 \mathrm{mg} \mathrm{m}^{-3}$ between 31 March and 10 May; insufficient nitrogen (IN) = peak chlorophyll concentration $<60 \mathrm{mg} \mathrm{m}^{-3}$ and $\left[\mathrm{NO}_{3}{ }^{-}\right]<1 \mu \mathrm{M}$ before 30 April; and insufficient phosphorous (IP) $=$ peak chlorophyll concentration $<60 \mathrm{mg} \mathrm{m}^{-3}$ and $\left[\mathrm{NO}_{3}{ }^{-}\right]>1 \mu \mathrm{M}$ after 30 May. These spring blooms of the dinoflagellate Prorocentrum minimum are a sporadic feature of the upper Chesapeake Bay (Tyler \& Seliger 1978) that can have large effects on light penetration and submerged vegetation survival in years and locations where they are intense (Gallegos \& Bergstrom 2005). These localized and sporadic blooms of $P$. minimum are superimposed on a more recurrent annual cycle of spring diatom bloom along the main axis of the bay governed by flow-induced stratification and $\mathrm{N}$ delivery (Malone et al. 1988).

Analysis of the annual component of $P_{H, T}$ proceeded by log-transforming Eq. (2) with its spectral correction factor to give a linear model for the logarithm of daily production in terms of its factors:

$$
\ln \left(P_{H, T}\right)=\ln (A)+\ln \left[F_{0, H}\left(E_{*}^{\mathrm{m}}\right)\right]+\ln \left[S\left(Z_{\mathrm{OD}}\right)\right]
$$

It was found that $\ln (A)$ was by far the dominant contributor to $\operatorname{var}\left(P_{H, T}\right)$ (Gallegos 2014); therefore, $\ln (A)$ was further analyzed in terms of its factors by natural log-transformation:

$$
\ln (A)=\ln (B)+\ln \left(P_{\text {max }}^{B}\right)+\ln (D)-\ln \left(K_{\mathrm{d}}\right)
$$

and

$$
\begin{aligned}
\operatorname{var}[\ln (A)]= & \operatorname{var}[\ln (B)]+\operatorname{var}\left[\ln \left(P_{\max }^{B}\right)\right] \\
& +\operatorname{var}[\ln (D)]+\operatorname{var}\left[\ln \left(K_{\mathrm{d}}\right)\right] \\
& +2 \operatorname{cov}\left[\ln (B), \ln \left(P_{\max }^{B}\right)\right] \\
& +2 \operatorname{cov}[\ln (B), \ln (D)] \\
& +2 \operatorname{cov}\left[\ln \left(P_{\max }^{B}\right), \ln (D)\right] \\
& -2 \operatorname{cov}\left[\ln \left(K_{\mathrm{d}}\right), \ln (B)\right] \\
& -2 \operatorname{cov}\left[\ln \left(K_{\mathrm{d}}\right), \ln \left(P_{\max }^{B}\right)\right] \\
& -2 \operatorname{cov}\left[\ln \left(K_{\mathrm{d}}\right), \ln (D)\right]
\end{aligned}
$$

Eq. (5) attributes proportional changes in $P_{H, T}$ to proportional changes in the scale factor $(A)$, the dimensionless depth integral, and spectral correction factor. Eq. (6a) performs the same partitioning on $A$ in term of its factors. Eq. (6b) is an exact expression for the fractional variance in $A$ in terms of the fractional variances (var) of the factors and their covariances (cov). These covariance terms are potentially interesting and important additions to or subtractions from the overall variance in production.

Interannual patterns in the factors in Eqs. (5) \& (6) were extracted from the data using the GLM procedure in the DataDesk 6.1 software. GLM estimates the coefficient vectors in the general relation:

$$
\begin{aligned}
y= & \text { Constant }+b_{0}(\text { Month })+b_{1}(\text { Station })+ \\
& b_{2}(\text { Year })+b_{3}(\text { Month } \times \text { Station })+\text { error }
\end{aligned}
$$

where $y$ is the response variable; $b_{j}$ are the coefficient vectors; Station, Month, and Year were treated as categorical variables; and error is the residual not explained by the categories or interactions, and consists of measurement uncertainties and 'event-scale' variability, broadly construed. Analysis of the seasonal (Month) and spatial (Station) components and their interaction are presented elsewhere (Gallegos 2014). Because the scalar term, $A$, primarily determines the magnitude of $P_{H, T}$, analysis of the terms on the right hand side of Eq. (6) permits ranking of the relative importance of variations in biomass, $P_{\max }^{B}$, photoperiod, and light attenuation as well as their variances and covariances to overall levels of production and their interannual variances.

The GLM analyses of $P_{\mathrm{A}}$ described above employed similar procedures with numerical (NAO) or 
categorical (AQ, $\mathrm{SQ}$, bloom classification) predictors. Based on the results of the GLM analysis of $P_{\mathrm{A}}$, an additional analysis was conducted on $P_{H, T}$ substituting bloom category $(B L C)$ for Year, and allowing interactions between Month $\times B L C$ to further discern the effect of major blooms on the seasonality of annual production. For this analysis, the output of the GLM on natural-log transformed production was converted back into arithmetic estimates of $P_{H, T}$ as $\exp \left[\ln \left(\hat{P}_{H, T}\right)+s^{2} / 2\right]$, where $\ln \left(\hat{P}_{H, T}\right)$ is the GLM prediction for $\ln \left(P_{H, T}\right)$ and $s^{2}$ is the variance of the residuals. Addition of the $s^{2} / 2$ is needed because exponentiation of the logarithmic mean is an estimate of the geometric mean, which is always smaller than the arithmetic mean (Hayes \& Shonkwiler 2006).

\section{Modeling primary production}

Assuming that $B$ and $K_{\mathrm{d}}$ can be readily measured in a continuing water quality monitoring program and $E_{0}$ monitored instrumentally, the only unknowns in Eq. (2) are $P_{\max }^{B}$ and $E_{\mathrm{k}}$. Therefore, the skill in modeling $P_{H, T}$ depends on the success in modeling these parameters and the sensitivity of $P_{H, T}$ to these parameters relative to those readily measured. Three modeling approaches with increasing levels of detail were compared based on (1) use of the overall mean $P$-E parameters (Mean-parameter model), (2) seasonal-spatial mean parameters determined by GLM analysis of $P$-E parameters with Month and Station as categorical variables (GLM), and (3) statistical regressions of the $P$ - $E$ parameters on environmental covariates (regression model). Preliminary use of the statistical regression model for $P_{\max }^{B}$ reported by Gallegos (2012) revealed that the underestimation by that model of $P_{\max }^{B}$ in late summer and early autumn led to systematic underestimation of $P_{H, T}$. The regression model, which included $\ln ($ temperature $[T])$, dissolved inorganic carbon (DIC), $\ln (B)$, and $\ln \left(K_{\mathrm{d}}\right)$ as predictors, was revised here by allowing an interaction term between month and DIC and dependence on station. The form of the regression model is:

$$
\begin{aligned}
\sqrt{P_{\max }^{B}=} & C_{0}+C_{1} \ln (T)+C_{2}[\mathrm{DIC}]+C_{3} \ln (B)+ \\
& C_{4} \ln \left(K_{\mathrm{d}}\right)+C_{4}(\text { Month })[\mathrm{DIC}]+C_{5}(\text { Station })
\end{aligned}
$$

where the $c_{j}$ coefficients are given below (see 'Results', Table 3), and the square-root transformation was done to normalize the data (Gallegos 2012). Data from odd numbered years (1557 measurements) were used to estimate coefficients in the GLM and regression models, and data from even numbered years (1702 measurements) were used for model evaluations.

\section{RESULTS}

\section{Annual production}

Over all stations and years annual primary production in the Rhode River ranged from 152 to 612 and averaged $328 \mathrm{~g} \mathrm{C} \mathrm{m}^{-2} \mathrm{yr}^{-1}(\mathrm{SD}=83.3, \mathrm{n}=114)$. Interannual variability was statistically significant (GLM, year categorical, $\mathrm{p}<10^{-4}$ ), but treating year as a continuous variable yielded no significant linear trend in $P_{\mathrm{A}}(\mathrm{p}>0.1)$, and a runs test about the mean revealed significant non-random variations for only 1 station (Stn 3.8, 7 runs, p = 0.05). The variability in annual production measured at the most upstream station, 5.2 , was considerably greater than that measured at lower estuary stations ( $\mathrm{km} 4.3$ and down estuary), typified by Stn 2.0 (Fig. 1A).

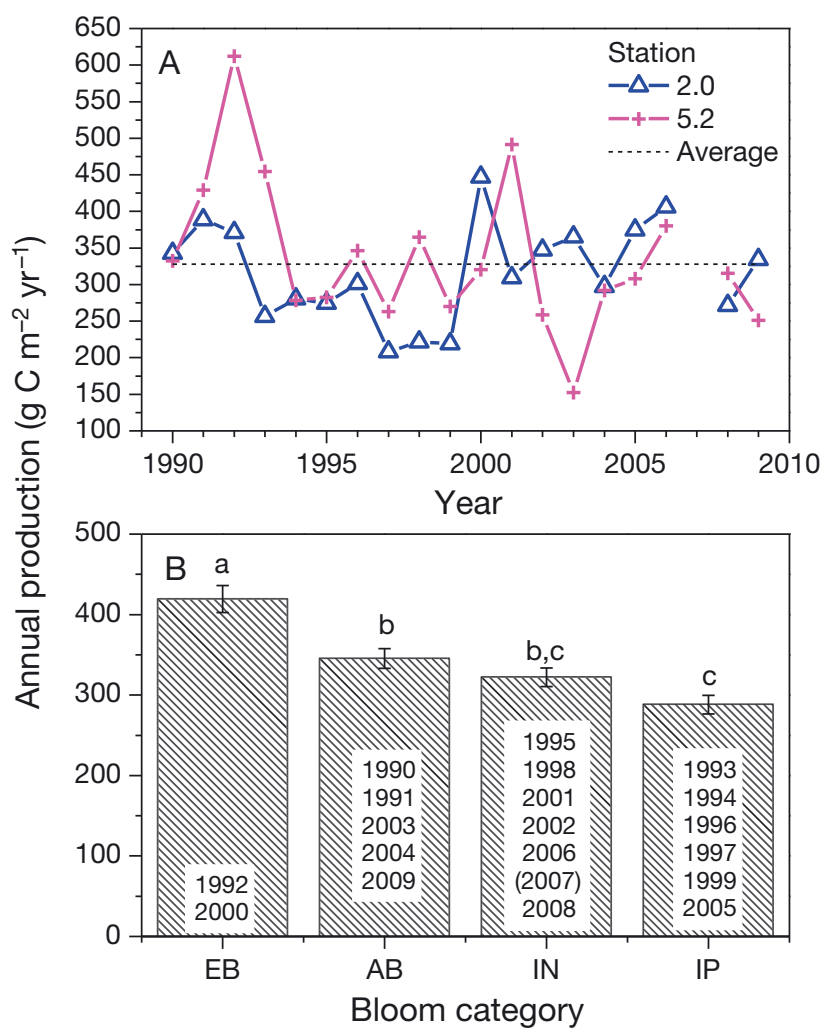

Fig. 1. (A) Annual phytoplankton production at 2 stations on the Rhode River, Maryland (USA) from 1990 to 2009. Stations are denoted by their distance from the mouth $(\mathrm{km}$, positive up-estuary). Dashed line is annual average for all stations and years. (B) Mean annual production for all years that fall into a given category of spring bloom of the dinoflagellate Prorocentrum minimum (biomass data indicate that 2007 fell in IN category, but ${ }^{14} \mathrm{C}$ data were insufficient for calculation of $P_{\mathrm{A}}$ ): $\mathrm{EB}=$ extraordinary bloom; $\mathrm{AB}=$ average bloom; IN = insufficient nitrogen; IP = insufficient phosphorus. Criteria for bloom classification in terms of peak chlorophyll concentration and timing of nitrate depletion are given in the text. Error bars are $\pm 1 \mathrm{SE}$ 
None of the climatological indices based on NAO or flow of the Susquehanna River (AQ, SQ) were significant predictors of $P_{\mathrm{A}}$ (GLM, $\left.\mathrm{p}>0.25\right)$. Bloom category was a significant predictor of $P_{\mathrm{A}}$ (GLM, p < 0.001). Production in years with extraordinary blooms (EB) exceeded that in all others (mean $419 \mathrm{~g}$ C m ${ }^{-2} \mathrm{yr}^{-1}$ ), while $P_{\mathrm{A}}$ in years with average blooms (AB, mean $345 \mathrm{~g} \mathrm{C} \mathrm{m}^{-2} \mathrm{yr}^{-1}$ ) exceeded $P_{\mathrm{A}}$ in years classified as insufficient $\mathrm{P}$ (IP, mean $288 \mathrm{~g} \mathrm{C} \mathrm{m}^{-2} \mathrm{yr}^{-1}$ ), but not in those classified as insufficient $\mathrm{N}$ (IN, mean $322 \mathrm{~g} \mathrm{C} \mathrm{m}^{-2} \mathrm{yr}^{-1}$ ) (Fig. 1B). Only $2 \mathrm{yr}$ were classified as EB during the $20 \mathrm{yr}$ of observation, while the remaining years were nearly evenly distributed amongst the other 3 categories (Fig. 1B).

Because $P_{\mathrm{A}}$ is determined by integration of the seasonal variation in daily production, insight into the role of spring blooms in creating interannual variations in production may be gained by examining the effect of the interaction term, Month $\times B L C(B L C$ substituting for Year), on the seasonal pattern of daily production at a gradient of stations (Fig. 2). At outer estuary sites (Stns 3.8 and seaward), the bloom category made a large difference in the production in the spring, such that the production peaked in May during years with EB. The relative magnitude of the May peak in production with EB decreased up-estuary, so that by Stn 4.3 production peaked in summer in all bloom categories (Fig. 2). At all stations, the rank order of production in the spring followed that for $P_{\mathrm{A}}$, i.e. $\mathrm{EB}>\mathrm{AB} \approx \mathrm{IN}>\mathrm{IP}$ (cf. Figs. $2 \& 1 \mathrm{~B}$ ). Additionally, production in August was higher at all stations in years with EB than in other categories of years, and blooms made no discernible difference from September onward (Fig. 2). The correspondence of bloom category with Susquehanna River flow climatology was not strong, as expected by the lack of significance of flow climatology in the GLM. Nevertheless, some consistencies emerged (Table 1) such as the occurrence of EB exclusively in years with dry springs, and 4 of 6 yr classified as IP occurred in wet springs (Table 1).

There was a strong correlation $\left(\mathrm{R}^{2}=0.91, \mathrm{n}=114\right.$, $\mathrm{p}<10^{-4}$ ) between the yearly average of daily production, $\bar{P}_{H, T}$, and annual integrated production, $P_{\mathrm{A}}$ (Fig. 3). Therefore, analyzing the determinants of the GLM coefficients for the annual factor of daily production according to Eq. (6) can shed light on the relative importance of factors controlling the magnitude and variance of annual primary production. The relationship of $P_{\mathrm{A}}$ to $\bar{P}_{H, T}$ (Fig. 3) was independent of station (GLM, p > 0.5), but more detailed analysis of spatial variability (Gallegos 2014) revealed spatial gradients in the factors controlling production, par-
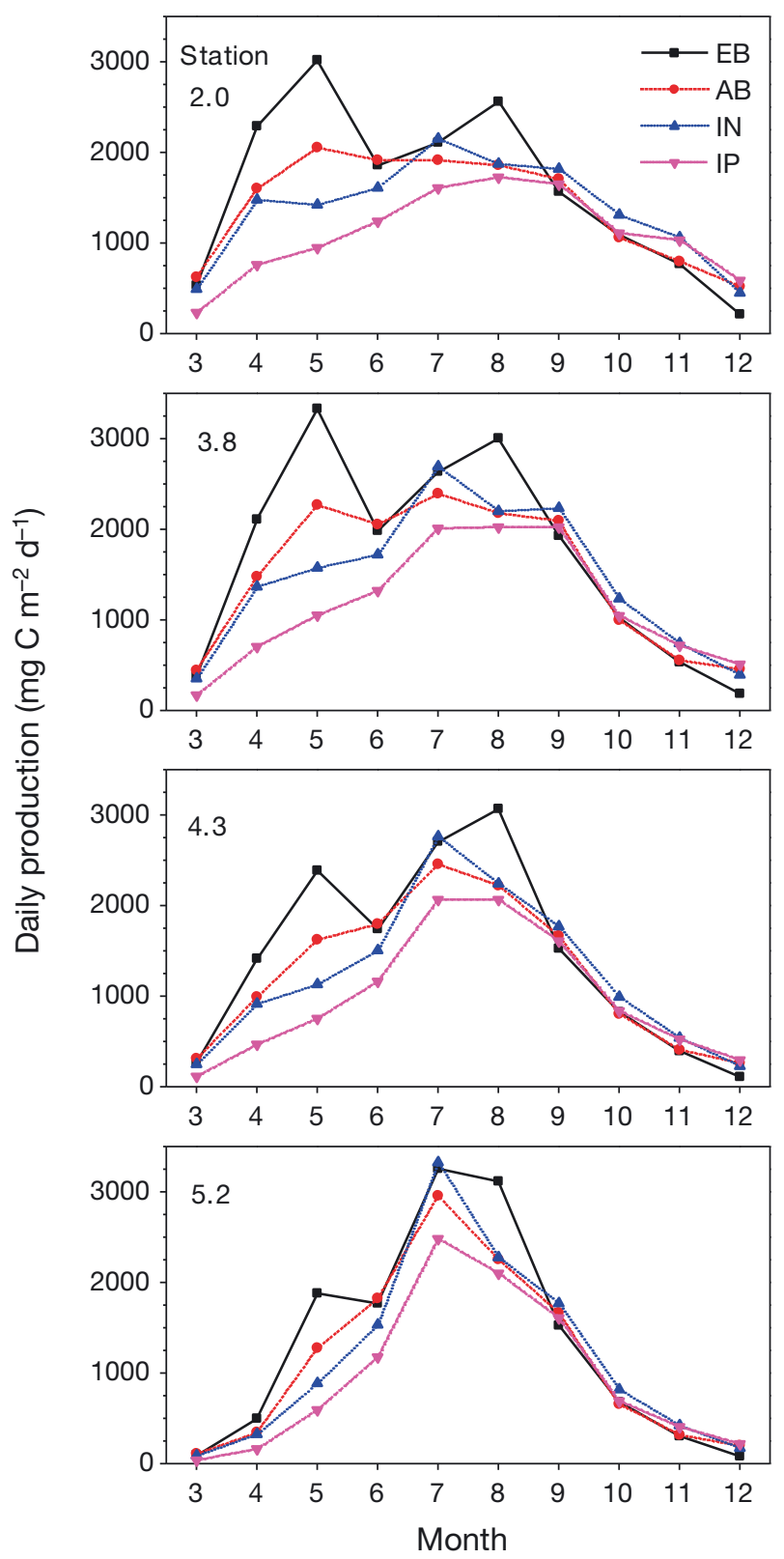

Fig. 2. Seasonal variation of production estimated from General Linear Model (GLM) for 4 categories of spring dinoflagellate bloom at 4 stations designated on the panels by distance from mouth $(\mathrm{km})$. Bloom categories as in Fig. 1. Seasonal patterns at stations further down estuary were similar to that at Stn 2.0

ticularly at the uppermost station (5.2) compared with lower estuary stations (4.3 and down estuary); therefore, the distinction between lower and upper estuary stations will be retained for analysis of interannual controls. Fig. 3 also provides a basis for determining the average daily production that is associated with an annual production of $300 \mathrm{~g} \mathrm{C} \mathrm{m}^{-2} \mathrm{yr}^{-1}$, the transition between eutrophic and mesotrophic 
Table 1. Contingency table of bloom categories (rows) with climatological classification of the spring freshet (columns). Freshet climatology classification was based on cumulative flow (March through May) of the Susquehanna River: Dry (D), flow <25th percentile; wet (W), flow $>25$ th percentile; normal $(\mathrm{N})$ all others. Criteria for spring dinoflagellate bloom classifications given in text: $\mathrm{EB}=$ extraordinary bloom; $\mathrm{AB}=$ average bloom; IN = insufficient nitrogen $; \mathrm{IP}=$ insufficient phosphorus

\begin{tabular}{|c|c|c|c|c|}
\hline \multirow{2}{*}{$\begin{array}{l}\text { Bloom } \\
\text { category }\end{array}$} & \multirow[b]{2}{*}{$\mathrm{D}$} & \multicolumn{2}{|c|}{ Freshet climatology } & \multirow[b]{2}{*}{ Total } \\
\hline & & $\mathrm{N}$ & $\mathrm{W}$ & \\
\hline EB & 2 & 0 & 0 & 2 \\
\hline $\mathrm{AB}$ & 3 & 1 & 2 & 6 \\
\hline IN & 2 & 2 & 2 & 6 \\
\hline IP & 1 & 1 & 4 & 6 \\
\hline Total & 8 & 4 & 8 & 20 \\
\hline
\end{tabular}

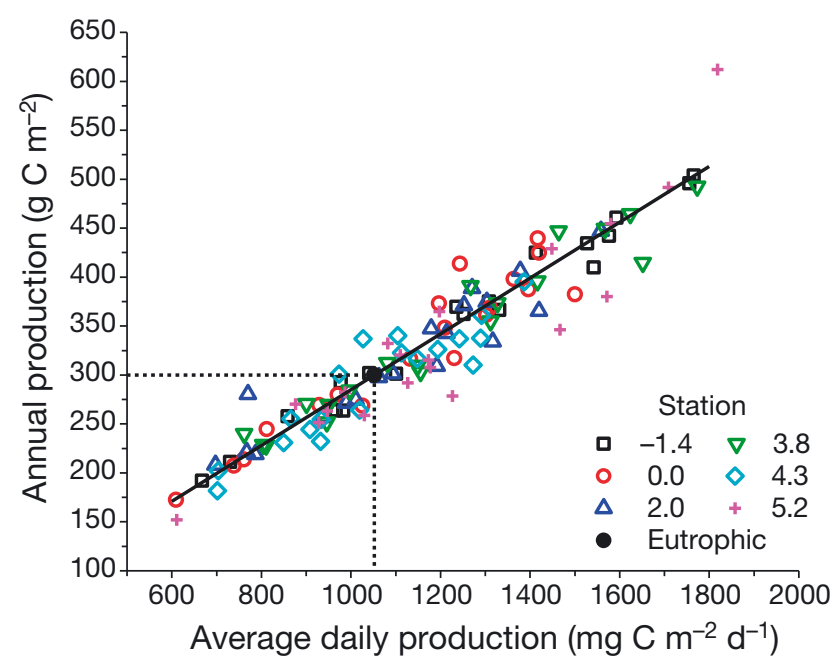

Fig. 3. Annual integrated production as a function of annual mean daily production at 6 stations on the Rhode River. Dotted lines identify $1052 \mathrm{mg} \mathrm{C} \mathrm{m}^{-2} \mathrm{~d}^{-1}$ as average daily production associated with $300 \mathrm{~g} \mathrm{C} \mathrm{m}^{-2}$ annual production, the indicator of eutrophic conditions (see 'Discussion' section 'Practical application')

conditions (Nixon 1995). Based on a type-II linear regression of $P_{\mathrm{A}}$ and $\bar{P}_{H, T 1}$ it was determined that $300 \mathrm{~g} \mathrm{C} \mathrm{m}^{-2} \mathrm{yr}^{-1}$ was obtained at an average daily production of $1052 \mathrm{mg} \mathrm{C} \mathrm{m}^{-2} \mathrm{~d}^{-1}$ (Fig. 3, filled circle and dashed lines).

\section{Interannual variations in daily production}

GLM analysis of the terms on the right hand side of Eq. (5) revealed that, similar to seasonal and spatial variations (see Gallegos 2014), the interannual variation in $\ln \left(P_{H, T}\right)$ was strongly dominated by the variation in the scalar term, $\ln (A)$ (not shown). The following analysis will, therefore, focus on the deter- minants of $\ln (A)$, and, because it makes use of Eqs. (5) \& (6), the logarithmic designations will be dropped for notational convenience. The factors governing the interannual variability in $A$ were complex and varied with location (Eq. 6, Fig. 4). Photoperiod, which does not vary with year, is included for proper scaling. Relative variations in $B$ and in $P_{\max }^{B}$ in the lower estuary were of similar magnitude in their influence on proportional variation in $A$ (Fig. 4A), although $B$ is numerically larger. The GLM coefficient for $K_{\mathrm{d}}$ varied erratically in the lower estuary up until 2002, and was relatively stationary for the remaining years (Fig. 4A). The coefficient on Year for $K_{\mathrm{d}}$ was uncorrelated with that of $B$ or $P_{\max }^{B}$. At the upper station, the relative variations in $B$ and $P_{\max }^{B}$ were also of similar magnitude in their influence on A (Fig. 4B). The overall magnitude of $K_{\mathrm{d}}$ was larger at the upper station than in the lower estuary, but

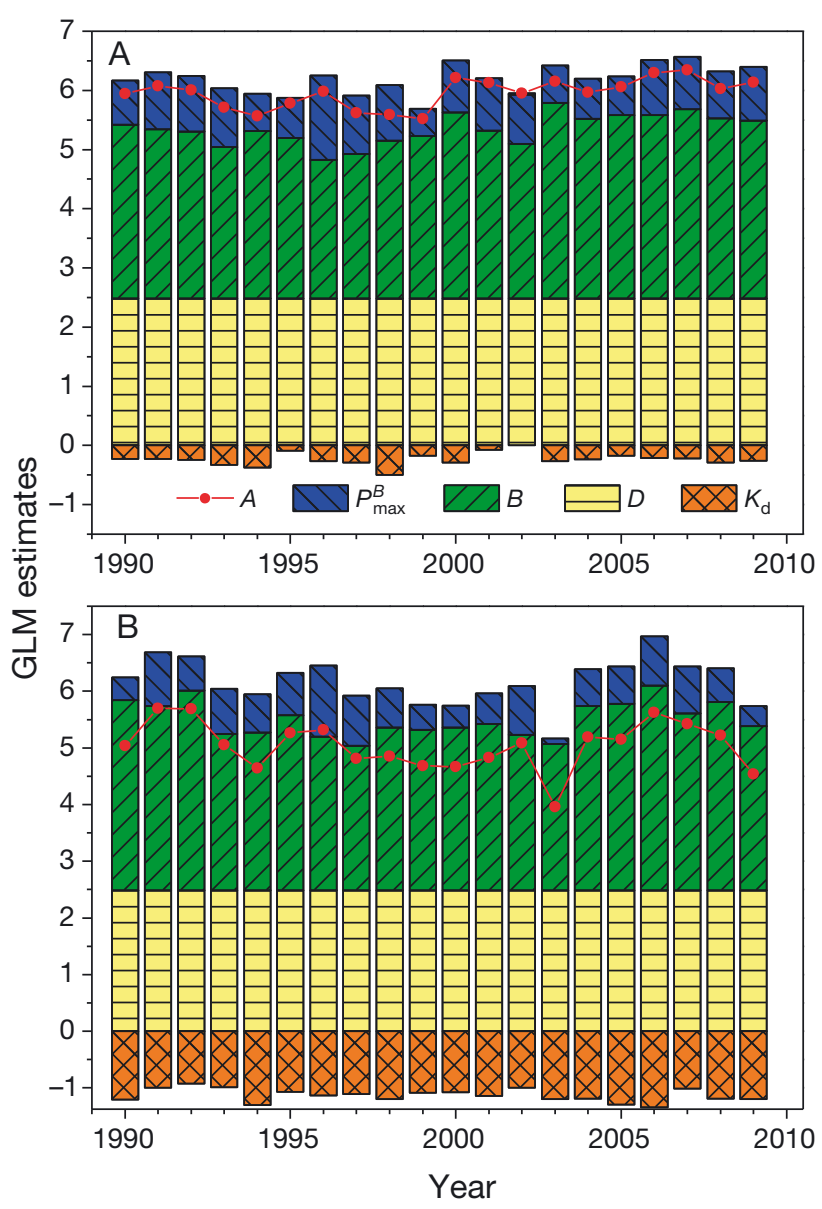

Fig. 4. (A) GLM estimates for the Year factor of the naturallog transformed scale factor, $A$, (filled circles) and the components comprising it (bars, see Eq. 6a): light-saturated, chlorophyll-specific carbon uptake rate, $P_{\max }^{B}$ (blue); chl a $(B)$ (green); photoperiod, $D$, shown for scale purposes only (yellow); diffuse attenuation coefficient, $K_{\mathrm{d}}$ (orange) lower estuary Stns 4.3 and seaward. (B) as (A), for the upper station, 5.2 
interannual variability in $K_{\mathrm{d}}$ at the upper station was comparatively weak (Fig. 4B).

The contributions to $A$ by $B$ and $P_{\max }^{B}$ frequently varied in opposite directions in the lower estuary, as for example in 1996-1998 when the contribution by $B$ was relatively low and that for $P_{\max }^{B}$ was consistently higher, and 2003-2005 when the reverse was true (Fig. 4A). This can be seen more clearly by examining the coefficients for the annual component $\left(b_{2}\right.$ in Eq. 7) for $P_{\max }^{B}$ plotted against those for $B$ (Fig. 5). The correlation was significantly negative $(\mathrm{R}=-0.49, \mathrm{p}=$ $0.026)$. Thus, in the lower estuary, there was a negative covariance between $B$ and $P_{\max }^{B}$ that dampened overall variance in $P_{H, T}$ at interannual time scales according to Eq. (6b). Annual GLM coefficients for $B$ and $P_{\max }^{B}$ were not correlated in the upper estuary (not shown, $\mathrm{R}=0.048, \mathrm{p}>0.4$ ).

\section{Modeling primary production}

Estimates of $P_{H, T}$ using the Mean-parameter model

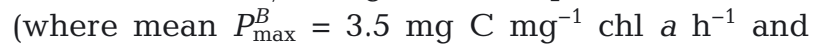
mean $E_{\mathrm{k}}=177.8 \mu \mathrm{mol} \mathrm{m}^{-2} \mathrm{~s}^{-1}$ ) with measured $B$ and $K_{\mathrm{d}}$ in Eq. (5) had the least precision of the 3 modeling approaches (Fig. 6, squares) with a mean percent error (MPE) of $29 \%$, relative root-mean-square error (RRMSE) of $135 \%$, coefficient of determination with measurements of 0.55 , and slope of 0.81 (Table 2). Use of seasonal-spatial GLM for the $P$-E parameters reduced the RRMSE and improved the correlation with measurements, but the MPE increased and

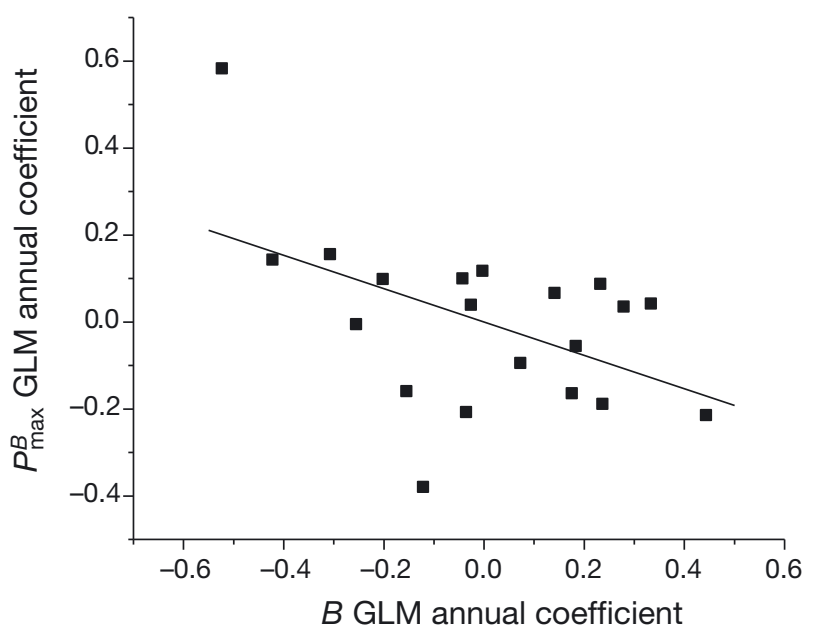

Fig. 5. GLM annual coefficients (i.e. $b_{2}$ in Eq. 7) for phytoplankton photosynthetic capacity, $P_{\max }^{B}$, plotted against GLM annual coefficients for chlorophyll biomass, $B$, for the Rhode River, lower estuary stations. Line is least-squares linear regression, $y r=-0.38 x-5.6 \times 10^{-6}\left(\mathrm{R}^{2}=0.25, \mathrm{p}=0.026\right.$ for slope)

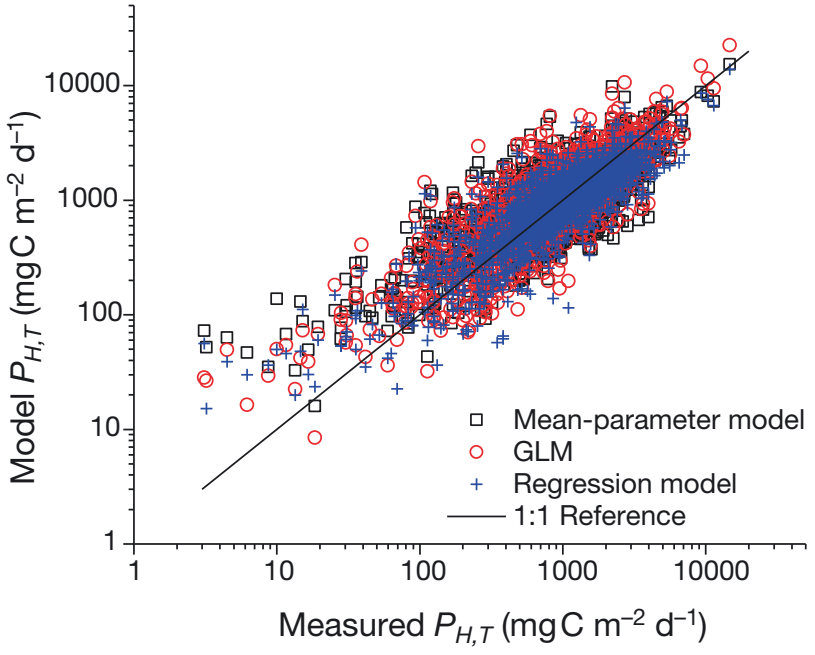

Fig. 6. Daily production calculated by different modeling approaches for estimating $P_{\max }^{B}$ in Eqs. (2) \& (3) plotted against measurements: (squares) $P_{\max }^{B}$ and $E_{\mathrm{k}}$ fixed at their long term averages (Mean-parameter model); (circles) $P_{\max }^{B}$ and $E_{\mathrm{k}}$ estimated from seasonal and spatial GLM (see Table 3); (crosses) $P_{\max }^{B}$ estimated from regression model with environmental covariates, and $E_{\mathrm{k}}$ estimated by seasonal and spatial GLM (see Table 3). Line is 1:1 reference

Table 2. Statistics of 3 model fits to measured daily production. Models consisted of an estimate of $P_{\max }^{B}$ and $E_{\mathrm{k}}$ and measured values of $B, D, K_{\mathrm{d}}$, and $E_{0}{ }^{\mathrm{m}}$ in Eq. (2). Meanparameter: average values of $P_{\max }^{B}$ and $E_{\mathrm{k}}$ used for all predictions; seasonal-spatial: General Linear Model (GLM) estimates of $P_{\max }^{B}$ and $E_{\mathrm{k}}$ with month and station as categorical variables; regression: GLM regression for $P_{\max }^{B}$ using $\ln ($ Temperature), dissolved inorganic carbon (DIC), $\ln (B), \ln \left(K_{\mathrm{d}}\right)$, and a month $\times$ DIC interaction term, with seasonal model for $E_{\mathrm{k}}$. Percent errors were calculated as 100(Predicted-Measured)/

Measured. RRMSE = relative root-mean-squared error

\begin{tabular}{|lccc|}
\hline Statistic & $\begin{array}{c}\text { Mean- } \\
\text { parameter } \\
\text { model }\end{array}$ & GLM & $\begin{array}{c}\text { Regression } \\
\text { model }\end{array}$ \\
\hline Mean percent error & $29.0 \%$ & $31.9 \%$ & $14.7 \%$ \\
RRMSE & $134.7 \%$ & $106.4 \%$ & $89.8 \%$ \\
R-squared & 0.55 & 0.63 & 0.66 \\
Slope & 0.81 & 0.70 & 1.02 \\
\hline
\end{tabular}

slope decreased compared with estimates made using constant means (Fig. 6, circles; Table 2). By every metric, the regression model produced the best agreement of modeled $P_{H, T}$ with measurements (Fig. 6, plusses), having the smallest MPE and RRMSE, and the highest $\mathrm{R}^{2}$ and slope closest to 1.0 (Table 2). All 3 approaches tended to overpredict $P_{H, T}$ at low measured values $<\sim 100 \mathrm{mg} \mathrm{C} \mathrm{m}^{-2} \mathrm{~d}^{-1}$ (Fig. 6). Coefficients for the seasonal-spatial GLM and regression model are given in Table 3. As an exercise 
Table 3. Coefficients in seasonal-spatial and regression models of $P_{\max }^{B}$ and $E_{\mathrm{k}}$. Coefficients of the regression model are for the square root of $P_{\max }^{B}$. Units of co-

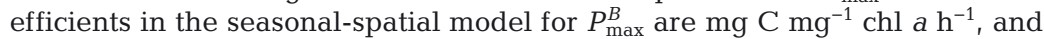
for $E_{\mathrm{k}}$ are $\mu \mathrm{mol}$ quanta $\mathrm{m}^{-2} \mathrm{~s}^{-1}$. Month and station coefficients in the regression model multiply concentrations of dissolved inorganic carbon (DIC). Units of coefficients in the regression model are $\left[\mathrm{mg} \mathrm{C} \mathrm{mg}^{-1} \mathrm{chl} \mathrm{a} \mathrm{h}^{-1}\right]^{1 / 2}$ divided by the units of the predictor (which are dimensionless for log-transformed predictors). All coefficients are statistically significant $(\mathrm{p}<0.05)$ except as noted $\left({ }^{\mathrm{ns}}\right)$

\begin{tabular}{|c|c|c|c|c|}
\hline \multirow[t]{2}{*}{ Predictor } & & \multicolumn{2}{|c|}{ GLM seasonal-spatial model } & \multirow{2}{*}{$\begin{array}{c}\text { Regression model } \\
\sqrt{P_{\max }^{B}}\end{array}$} \\
\hline & & $P_{\max }^{B}$ & $E_{\mathrm{k}}$ & \\
\hline Constant & & 2.93 & 100.1 & $-0.0040^{\mathrm{ns}}$ \\
\hline $\ln (T)$ & & & & 0.4020 \\
\hline DIC & & & & 0.0557 \\
\hline $\ln (B)$ & & & & -0.1340 \\
\hline $\ln \left(K_{\mathrm{d}}\right)$ & & & & 0.2100 \\
\hline \multirow{12}{*}{ Month } & 1 & -1.99 & -43.5 & -0.0201 \\
\hline & 2 & -2.05 & -38.8 & -0.0236 \\
\hline & 3 & -1.51 & -25.3 & -0.0200 \\
\hline & 4 & -0.59 & -9.4 & 0.0070 \\
\hline & 5 & -0.28 & 3.7 & 0.0060 \\
\hline & 6 & 0.31 & 30.8 & 0.0059 \\
\hline & 7 & 1.32 & 38.8 & 0.0089 \\
\hline & 8 & 1.72 & 39.1 & 0.0078 \\
\hline & 9 & 2.53 & 33.6 & 0.0136 \\
\hline & 10 & 1.26 & 7.0 & 0.0096 \\
\hline & 11 & $0.29^{\text {ns }}$ & -11.5 & 0.0093 \\
\hline & 12 & -1.00 & -24.4 & $-0.0044^{\mathrm{ns}}$ \\
\hline \multirow[t]{6}{*}{ Station } & -1.4 & 0.33 & $0.4^{\mathrm{ns}}$ & 0.0087 \\
\hline & 0.0 & -0.15 & -10.0 & $0.0010^{\mathrm{ns}}$ \\
\hline & 2.0 & -0.26 & $-4.2^{\mathrm{ns}}$ & $-0.0017^{\mathrm{ns}}$ \\
\hline & 3.8 & $0.02^{\text {ns }}$ & $2.9^{\text {ns }}$ & $0.0005^{\mathrm{ns}}$ \\
\hline & 4.3 & $0.06^{\mathrm{ns}}$ & $3.4^{\mathrm{ns}}$ & $-0.0021^{\mathrm{ns}}$ \\
\hline & 5.2 & $0.01^{\mathrm{ns}}$ & 7.5 & -0.0065 \\
\hline
\end{tabular}

plained variance in $P_{\max }^{B}$ rather than in $E_{*}^{\mathrm{m}}$, as expected.

Annual integration of the 3 model estimates of $P_{H, T}$ led to smaller relative errors between model predictions of annual production compared with daily estimates (Fig. 7A, Table 4). The different modeling approaches captured much of the interannual variability of $P_{\mathrm{A}}$ at a representative station, as expected by virtue of using measured $B, K_{\mathrm{d}}$, and (the same modeled) $E_{0}$ for all estimates of $P_{H, T}$ (Fig. 7A). Different modeling approaches gave estimates closer to measured annual integrals in different years (Fig. 7A), but over all stations and years the spread of the errors associated with the regression model was the smallest (Fig. 7B, Table 4). The regression approach explained $63 \%$ of the variance in measured $P_{\mathrm{A}}$ over all stations, compared with just over $50 \%$ for the other approaches (Table 4). When the production estimates were weighted by the areas of the different segments gauged by the stations (Jordan et al. 1991a), the explained variance was reduced to $\mathrm{R}^{2}=0.53$, due to poorer correlation at lower estuary stations that indexed greater areal dimensions.

to isolate the source of variance in the model predictions (not shown), use of the GLM estimates of $E_{\mathrm{k}}$ with measured $P_{\max }^{B}$ reproduced measurements with $\mathrm{R}^{2}=0.98$ and slope $=0.996$, indicating that nearly all of the uncertainty in estimated $P_{H, T}$ is due to unex-
Finally, there are sufficient data to perform a power analysis to address questions related to detection of a change in trophic status based on the criteria of Nixon (1995). For example, the number of years needed to detect whether area-weighted production
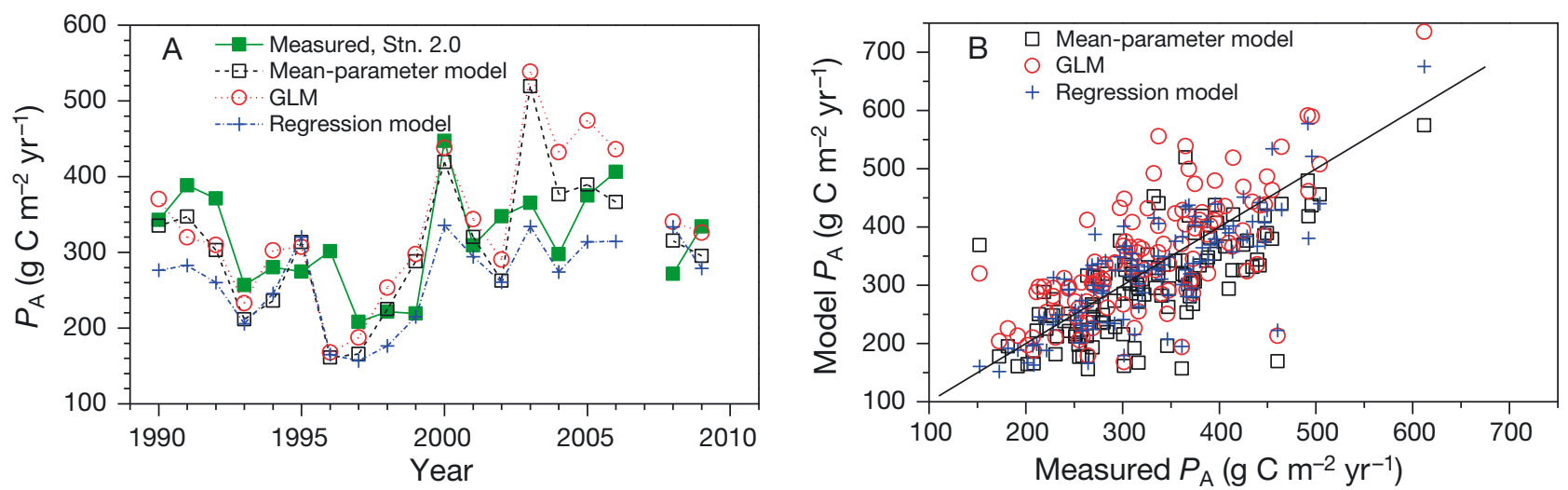

Fig. 7. (A) Interannual variation in annual phytoplankton production $\left(P_{\mathrm{A}}\right)$ at lower estuary Stn 2.0 calculated by integration of measured daily production (filled squares) and values calculated by 3 modeling approaches for estimating $P_{\text {max }}^{B}$ (symbols as in Fig. 6). (B) Annual production estimated by 3 modeling approaches (symbols as in Fig. 6) plotted against values calculated from measurements for all stations and years. Line is 1:1 reference 
has dropped below, for instance, $300 \mathrm{~g} \mathrm{C} \mathrm{m}^{-2} \mathrm{yr}^{-1}$ depends on the level of reduction achieved and the variance of the estimate (Cohen 1992). Three levels of reduction were considered, 250, 225, and $200 \mathrm{mg}$ $\mathrm{C} \mathrm{m}^{-2} \mathrm{yr}^{-1}$ (Table 5). Taking the coefficient of variation of annual production as $21 \%$, and assuming the model estimates capture $53 \%$ of the variance, the number of years of measurements needed to detect such a change with power $>0.8$ ranges from 3 to $9 \mathrm{yr}$ if measurements of $P-E$ parameters were continued, or 4 to $15 \mathrm{yr}$ when estimating production by the empirical regression model (Table 5).

\section{DISCUSSION}

\section{Annual production}

Annual primary production in the Rhode River was similar in magnitude to the main stem of the Chesapeake Bay (Boynton et al. 1982, Harding et al. 2002) because shallower depths of the Rhode River were partially offset by higher chl a concentrations there. These levels of annual production qualify the system as eutrophic by the classification of Nixon (1995) and are similar to primary production in other eutrophic coastal areas (Borum 1996, Yoshiyama \& Sharp 2006). The lack of trends in $P_{\mathrm{A}}$ over the $20 \mathrm{yr}$ of measurements indicates that the system is not undergoing further eutrophication (Nixon 1995). Available measurements from 1970-1972 of chl a (Seliger \& Loftus 1974, Gallegos et al. 2010) and $P_{\max }^{B}$ (4-10 $\mathrm{mg} \mathrm{C} \mathrm{mg}^{-1}$ chl $a \mathrm{~h}^{-1}$, Loftus et al. 1972) suggest that $P_{\mathrm{A}}$ in the Rhode River was roughly similar at that time to levels reported here. Otherwise, there are no measurements to establish whether (or when) the system was ever anything other than eutrophic. There are, however, reports of populations of submerged vascular plants disappearing in the late 1960s (Southwick \& Pine 1975), a common system-wide response to eutrophication (Borum 1996, Cloern 2001, Krause-Jensen et al. 2012). Given the strong dependence of the lower stations of the Rhode River on conditions in the adjacent shoulders of the Chesapeake Bay (Fig. 2A, see also Seliger \& Loftus 1974), it is likely that increases in chl $a$ and $P_{\mathrm{A}}$ in the Rhode River occurred on a similar time frame as in the main stem of the Chesapeake Bay, i.e. between the early 1950s and 1970s (Harding \& Perry 1997). A similar
Table 4. Statistics of model predictions of annual production by 3 models: mean-parameter, constant, average values used for $P_{\max }^{B}$ and $E_{\mathrm{k}}$ GLM, $P_{\max }^{B}$ and $E_{\mathrm{k}}$ estimated from General Linear Model (GLM) with month and station as categorical predictors; regression model, $P_{\max }^{B}$ estimated by regression on temperature, DIC, chl $a$, and $K_{\mathrm{d}}$ (see Table 2)

\begin{tabular}{|lccc|}
\hline Statistic & $\begin{array}{c}\text { Mean- } \\
\text { parameter } \\
\text { model }\end{array}$ & GLM & $\begin{array}{c}\text { Regression } \\
\text { model }\end{array}$ \\
\hline Mean percent error & $8.14 \%$ & $7.41 \%$ & $-1.50 \%$ \\
RRMSE & $24.1 \%$ & $24.1 \%$ & $17.0 \%$ \\
R-squared & 0.51 & 0.52 & 0.63 \\
Slope & 0.75 & 0.88 & 0.87 \\
\hline
\end{tabular}

time frame is indicated for European estuaries for which longer term measurements of $P_{\mathrm{A}}$ are available (Richardson 1996, Andersen et al. 2006).

Failure of the climate indicators based on flow of the Susquehanna River to predict $P_{\mathrm{A}}$ in the Rhode River differs from the situation in the main stem of the Chesapeake Bay, where annual production was shown to vary linearly with $\mathrm{N}$ loading in February (positively weighted) and March (negatively weighted) (Harding et al. 2002). In the main stem of the Chesapeake Bay, years of high freshwater flow expand the range of nutrient sufficiency further seaward than in low-flow years, so that the main diatom spring bloom is larger by virtue of greater nutrient input (and increased stratification) than in low-flow years (Malone et al. 1988, Harding et al. 2002). In this sub-estuary located in the mesohaline region, the dependence of production on flow is more complex because the highest flows bring turbid water and cause increased flushing, so that the highest nutrient loadings are not utilized within the sub-estuary. Two such years, 1993 and 1994, which had the lowest observed spring salinities at the mouth $(<3)$ and highest April N loading by the Susquehanna River, were observed to have lower than average annual chlorophyll bio-

Table 5. Power analysis to determine number of years $(\mathrm{N})$ of estimates of annual production in the Rhode River that would be necessary to detect a mean level (far left column) less than $300 \mathrm{~g} \mathrm{C} \mathrm{m}^{-2} \mathrm{yr}^{-1}$ by measurements, or by model estimates. Standard deviation (SD) assumes a coefficient of variation of $21 \%$ for measurements, and $28.9 \%$ for model estimates. Effect size is standardized measurement of the mean below the reference level of $300 \mathrm{~g} \mathrm{C} \mathrm{m}^{-2} \mathrm{yr}^{-1}$. Units of mean and SD are $\mathrm{g} \mathrm{C} \mathrm{m}^{-2} \mathrm{yr}^{-1}$

\begin{tabular}{|lcccccrrr|}
\hline \multirow{2}{*}{ Mean } & \multicolumn{3}{c}{ Measured production } & \multicolumn{3}{c|}{ Model-estimated production } \\
& SD & Effect size & N & Power & SD & Effect size & N & Power \\
\hline 250 & 52.5 & 0.952 & 9 & 0.831 & 72.1 & 0.693 & 15 & 0.815 \\
225 & 47.3 & 1.587 & 5 & 0.893 & 64.9 & 1.156 & 7 & 0.852 \\
200 & 42.0 & 2.381 & 3 & 0.821 & 57.7 & 1.733 & 4 & 0.831 \\
\hline
\end{tabular}


mass (Gallegos et al. 2010) and lower than average production in the lower estuary (Fig. 1A).

The presence or absence of major spring blooms of the dinoflagellate Prorocentrum minimum was found to be a significant predictor of interannual variability in $P_{\mathrm{A}}$ in the Rhode River (Fig. 1B). While there is some circularity in using a phytoplankton biomass indicator to explain the variability, the mechanism is not trivial. In the 2 yr classified as EB, production in the spring exceeded that in summer only at the outer stations, 3.8 and seaward (Fig. 2). Peak production remained in summer, well after subsidence of the bloom itself, in up-estuary stations (4.3 and 5.2) and at all stations in years with $\mathrm{AB}$ (Fig. 2). This suggests that summertime recycling of nutrients trapped upon termination of the spring bloom fuels higher production in bloom years (Jordan et al. 1991b). In that regard, the sub-estuary resembles the main stem of the bay, with sediment release substituting for the role of sub-pycnocline diffusion as the nutrient source fueling the summertime production maximum (Malone et al. 1988).

Nevertheless, major Prorocentrum minimum blooms in the Rhode River are flow dependent. It has been demonstrated by high frequency automated monitoring of salinity (a surrogate for $\mathrm{NO}_{3}$ input) and optical properties (showing response of phytoplankton chlorophyll, Gallegos \& Jordan 2002) that such blooms are triggered by nutrients delivered when the spring freshet of the Susquehanna River causes a reversal of the normal salinity gradient, leading to rapid exchange of water in the sub-estuary (Schubel \& Pritchard 1986). Such detailed observations are not available for most years, but both years having EB in this study $(1992,2000)$ were categorized as having dry spring flows (Table 1). Thus, it may be that the largest blooms are a response to the pulsed addition of nutrients following a time when they had previously been scarce. If so, the expected mode of climate change for the mid-Atlantic USA, consisting of increased frequency and severity of droughts and flooding (Najjar et al. 2010), could exacerbate major dinoflagellate blooms in sub-estuaries; though as noted, the largest floods do not produce $P$. minimum blooms in this system and are more often associated with years classified as IP (Table 1).

\section{Factors regulating primary production}

Because Eqs. (5) \& (6) are linear and based on an exact solution of the daily depth-integral of production, the equations apply on any relevant temporal (>1 d) or spatial scale. Certain covariance terms dis- played contrasting patterns on different time scales, indicative of the processes regulating the variance in primary production at particular scales. For example, on seasonal time scales, there was a positive covariance between $B$ and $P_{\max }^{B}$, due to similar winterspring minima and summer maxima in each. This positive covariance augmented the variance in $P_{H, T}$ (Gallegos 2014). At interannual time scales, the GLM analysis revealed a negative covariance between the same 2 parameters in the lower estuary that damped the year-to-year variance in $P_{H, T}$ (Figs. $4 \mathrm{~A} \& 5$ ).

\section{Modeling primary production}

The compact exact solution to the equation for depth-integrated production (Eq. 2) provides a convenient expression for modeling $P_{H, T}$ that has received considerable use in regional remote sensing studies (Forget et al. 2007, Platt et al. 2008). Simpler approaches based on proportionality of $P_{H, T}$ with the composite parameter $B \int E_{0} / K_{\mathrm{d}}$ (where $\int E_{0}$ is the daily integral of incident irradiance) have been applied with varying success in estuaries (Cole \& Cloern 1987, Brush \& Brawley 2009, see review in Parker et al. 2012). Bouman et al. (2010) demonstrated that the proportionality provided a reasonable approximation because, at medium-to-high irradiance as frequently encountered in field studies, $F_{0, \infty}\left(E_{*}^{\mathrm{m}}\right)$ is approximately linear, and that information on $P_{\max }^{B}$ and $\alpha^{B}$ could be extracted from the intercept and slope of the regression of $P_{H, T}$ against $B \int E_{0} / K_{\mathrm{d}}$. Given this close relationship between the 2 approaches and that the exact solution is computationally simple and is expressed in physiologically meaningful terms, we may conclude that use of Eq. (2) or (4) for modeling estuarine productivity is preferable to an empirical regression against $B \int E_{0} / K_{\mathrm{d}}$, even if only system means are available for $P_{\max }^{B}$ and $E_{\mathrm{k}}$, and all the more so if the physiological parameters can be estimated from robust, sitespecific models or historical catalogs.

The degree of scatter in the comparisons of measurements with model estimates using constant, mean $P-E$ parameters (Mean-parameter model, Fig. 6, Table 2) is consistent with the relative contributions of $B$ and $P_{\max }^{B}$ to the overall variance in $A$, the primary determinant of $P_{H, T}$ (Fig. 5A in Gallegos 2014). The improvement in model performance achieved by an empirical regression estimate for $P_{\max }^{B}$ (regression model, Table 4) is encouraging because the predictors in the relationship for $P_{\max }^{B}$ are responsive to global atmospheric change (temperature and DIC) or targeted for reduction by management ( $B$ and $K_{\mathrm{d}}$ ). Never- 
theless, the overall $\mathrm{R}^{2}$ was only 0.53 for area-weighted $P_{\mathrm{A}}$. Aside from the difficulty of recovering from eutrophication in a changing climate (Duarte et al. 2009), the power analysis indicates that detection of recovery in the context of normal climate variability may be similarly difficult (Table 5). The specific results for detection times based on the Rhode River data may not apply directly to other systems, because the analysis depends on the variance of the estimate. Some systems without such a repeatable seasonal pattern as here (e.g. Cloern \& Jassby 2010) could have higher variance of estimates, whereas in others where $P_{\max }^{B}$ is less variable (e.g. Canion et al. 2013), the variance (and associated time of detection) could be lower.

\section{Practical application}

The formalism of Platt \& Sathyendranath (1993) and the empirical observations here (Fig. 3) provide a basis for determining biomass levels needed to achieve a target annual production. For example, if we wished to determine a target biomass level, $B^{*}$, that would achieve a target average daily production, $P^{*}$, we can solve for $B^{*}$ if we fix a few parameters. In this system, the spectral correction factor, $S\left(Z_{\mathrm{OD}}\right)$, and dimensionless depth integral, $F_{0, H}\left(E_{*}^{\mathrm{m}}\right)$, were minor components in the variance of $P_{H, T}$ (Fig. 9A in Gallegos 2014). Treating these parameters as constant and solving Eq. (2) for the target value for the scalar, $A^{*}$, we get:

$$
A^{*}=\frac{P^{*}}{F_{0, H}\left(E_{*}^{\mathrm{m}}\right) S\left(Z_{\mathrm{OD}}\right)}
$$

Substituting into Eq. (3) and rearranging, we find:

$$
B^{*}=\frac{A^{*} K_{\mathrm{d}}}{P_{\max }^{B} D}
$$

We may approximate the diffuse attenuation coefficient as the sum of a background attenuation, $K_{\mathrm{T}}$ (due to water, colored dissolved organic matter, and non-algal particulates), and a chlorophyll dependent term with chlorophyll-specific attenuation, $k_{\mathrm{c}}$ i.e. $K_{\mathrm{d}}=K_{\mathrm{T}}+k_{\mathrm{C}} B^{*}$. Substituting into Eq. (9) and rearranging, we obtain:

$$
B^{*}=\frac{K_{\mathrm{T}} A^{*}}{P_{\max }^{\mathrm{B}} D-k_{\mathrm{c}} A^{*}}
$$

Treating $D$ and $k_{\mathrm{c}}$ as constants (e.g. Wofsy 1983), Eq. (10) may be viewed as linear in background attenuation, $K_{\mathrm{T}}$, with $P_{\max }^{B}$ as a parameter (Fig. 8A), or as hyperbolic in $P_{\max }^{B}$ with $K_{\mathrm{T}}$ as a parameter (Fig. 8B). Higher $B^{*}$ can be tolerated as background light
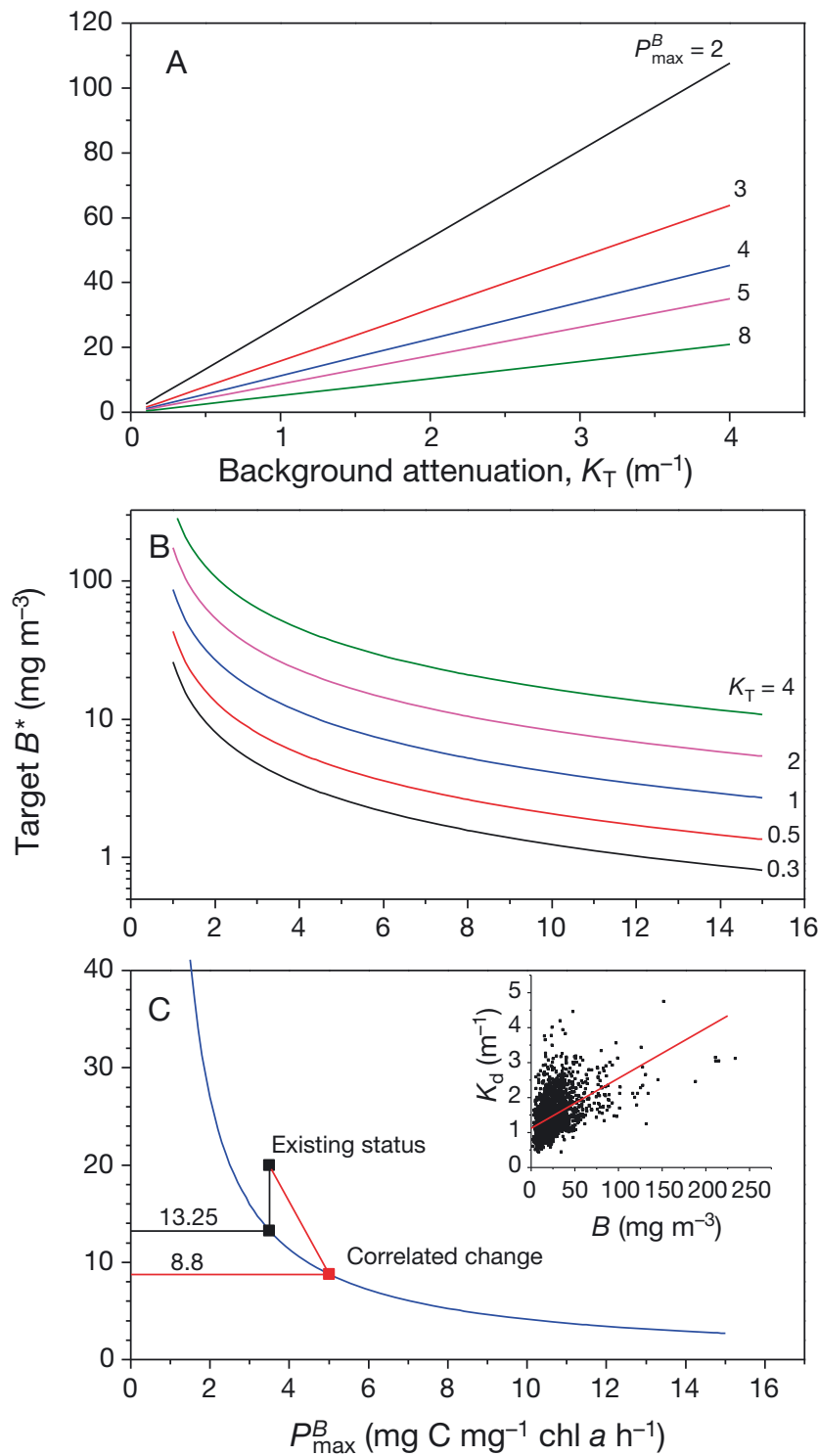

Fig. 8 Target concentration of $\mathrm{chl} a, B^{*}$, needed to achieve a daily production of $1052 \mathrm{mg} \mathrm{C} \mathrm{m}^{-2} \mathrm{~d}^{-1}$, which would produce a trophic classification of mesotrophic $\left(300 \mathrm{~g} \mathrm{C} \mathrm{m}^{-2} \mathrm{yr}^{-1}\right)$ in the Rhode River. (A) $B^{*}$ as a function of non-algal light attenuation, $K_{\mathrm{T}}$, with $P_{\max }^{B}$ as a parameter; (B) $B^{*}$ as a function of $P_{\max }^{B}$ with $K_{\mathrm{T}}$ as a parameter; (C) example hypothetical application to the Rhode River with existing conditions of $P_{\max }^{B}=$ $3.5 \mathrm{mg} \mathrm{C} \mathrm{mg}^{-1} \mathrm{chl} \mathrm{a} \mathrm{h}^{-1}$ and median $B=20 \mathrm{mg} \mathrm{m}^{-3}$ assuming (black line) no covariance between $B$ and $P_{\text {max }}^{B}$ and (red line) negative covariance between $B$ and $P_{\max }^{B}$. $B^{*}$ calculated by Eqs. (8) \& (10) with $F_{0, H}=2.4$ and $S\left(Z_{\mathrm{OD}}\right)=0.8$ (both dimensionless). Inset shows data for derivation of parameter $k_{\mathrm{c}}$

attenuation increases (Fig. 8A), or as $P_{\max }^{B}$ decreases (Fig. 8B). Interestingly, water depth does not enter the relationship because Eq. (2) is based on integration of the non-dimensionalized depth profile (Platt \& Sathyendranath 1993). Depth is, nevertheless, important implicitly, as the maximum standing crop that 
can be sustained in a water column depends on depth and background attenuation (Wofsy 1983), such that the highest biomass levels shown in Fig. 8B can only be attained in very shallow waters.

For application with data from the Rhode River, we can take the target daily production as $1052 \mathrm{mg} \mathrm{C} \mathrm{m}^{-2}$ $\mathrm{d}^{-1}$, i.e. the average daily rate that gave $300 \mathrm{~g} \mathrm{C} \mathrm{m}^{-2}$ $\mathrm{yr}^{-1}$ (Fig. 3). Fixing $S\left(Z_{\mathrm{OD}}\right)$ and $F_{0, H}\left(E_{*}^{\mathrm{m}}\right)$ near their respective mean values of 0.8 and 2.4 (Gallegos 2014), from Eq. (8) the target $A^{*}$ is $548 \mathrm{mg} \mathrm{C} \mathrm{m}^{-2} \mathrm{~d}^{-1}$. Taking $D$ as $14 \mathrm{~h}$ for summer conditions, $K_{\mathrm{T}}$ as $1.0 \mathrm{~m}^{-1}$, and $k_{\mathrm{c}}$ as $0.014 \mathrm{~m}^{2} \mathrm{mg}^{-1} \mathrm{chl}$ a (Fig. $8 \mathrm{C}$, inset), $B^{*}$ varies as the contour line in Fig. 8C. The median chlorophyll concentration would have to be reduced from the observed level of 20 to $13 \mathrm{mg} \mathrm{m}^{-3}$ (Fig. 8C, black lines) in order to intersect the curve at the observed average value for $P_{\max }^{B}$ of $3.5 \mathrm{mg} \mathrm{C} \mathrm{mg}^{-1} \mathrm{chl} \mathrm{a} \mathrm{h}{ }^{-1}$ (Gallegos 2012). Note, however, that Eq. (10) does not account for any possible covariance between $B$ and $P_{\max }^{B}$, such as observed here (Figs. $4 \mathrm{~A} \& 5$ ). If reduction of $B$ were to result in higher $P_{\max }^{B}$ for example by shifting community composition to smaller cells (Bouman et al. 2005, Adolf et al. 2006), then the target $B^{*}$ would be lower than that calculated by a vertical trajectory (Fig. 8C, red lines). In the hypothetical example shown with a shift to $P_{\max }^{B}=5 \mathrm{mg} \mathrm{C} \mathrm{mg}^{-1} \mathrm{chl} \mathrm{a} \mathrm{h}^{-1}$, (a reasonable value for temperate coastal marine systems, Harrison \& Platt 1980), the target $B^{*}(8.8 \mathrm{mg}$ $\mathrm{m}^{-3}$ ) would be $66 \%$ of that determined without considering such covariation, underscoring the importance of considering possible covariances embedded in the controlling variables. Additional statistical considerations related to risk or compliance assessment are beyond the scope of this demonstration. These targets are, however, within the range of chlorophyll criteria for shallow regions of the Chesapeake Bay determined by multiple (but differing) criteria (Harding et al. 2014). Some of the relationships used in this example are site-specific, such as the background attenuation (Fig. $8 \mathrm{C}$ inset) and the relationship for deriving $P^{*}$ (Fig. 3), that depend on the particular seasonality observed here, which is by no means universal (Cloern \& Jassby 2010). Nevertheless, the needed terms are relatively easy to determine, and the procedure, therefore, could find wide use in determining estuarine restoration goals.

\section{CONCLUSIONS}

Annual primary production in the Rhode River varied by a factor of $\approx 2$ over $19 \mathrm{yr}$ of measurements at all stations. The presence or absence of major spring dinoflagellate blooms was the main discernible factor controlling annual production, but the relationship of bloom occurrence to spring flow of the Susquehanna River is complex. In years that they occurred, major spring blooms of the dinoflagellate Prorocentrum minimum shifted peak production from summer to spring at lower estuary stations, but amplified the summer peak at upper estuary stations.

Log-transformation of the exact solution for calculating depth-integrated daily production is an effective way to partition the variance in production into contributions due to environmental and physiological factors, and their covariances. On interannual time scales, $B$ and $P_{\max }^{B}$ were negatively correlated, damping the variability over what would be the case if $B$ were similarly variable and uncorrelated with $P_{\max }^{B}$.

A continuing water quality monitoring program that determines chl $a$ and $K_{\mathrm{d}}$ but not $P$ - $E$ parameters can expect to capture about $63 \%$ of the variance in annual production at individual stations, or about $53 \%$ of area-weighted production in the whole river. Between 4 and 15 yr would be needed to detect a change in trophic state, depending on the magnitude of change. With a few simplifying assumptions, the equations for calculating production can be rearranged to estimate biomass levels needed to achieve a change in trophic state. For the Rhode River, chl a would need to be reduced to less than $13 \mathrm{mg} \mathrm{m}^{-3}$ to be classified as mesotrophic. The procedure should be useful in other coastal systems experiencing eutrophication.

Acknowledgements. I thank S. Hedrick for measurements of ${ }^{14}$ C uptake, and N. Kobayashi, A. M. Hartsig, K. Jarriel, and $\mathrm{S}$. Benson for assistance in the field. I thank T. Jordan for access to nutrient data, and L. Harding for regional climatology classifications. Funding was provided by the Smithsonian Environmental Sciences Program and Federal funds of the Smithsonian Institution.

\section{LITERATURE CITED}

Adolf JE, Yeager CL, Miller WD, Mallonee ME, Harding LW Jr (2006) Environmental forcing of phytoplankton floral composition, biomass, and primary productivity in Chesapeake Bay, USA. Estuar Coast Shelf Sci 67:108-122

Andersen JH, Schlüter L, Ertebjerg G (2006) Coastal eutrophication: recent developments in definitions and implications for monitoring strategies. J Plankton Res 28: 621-628

> Andersen $\mathrm{JH}$, Axe P, Backer $\mathrm{H}$, Carstensen $\mathrm{J}$ and others (2011) Getting the measure of eutrophication in the Baltic Sea: towards improved assessment principles and methods. Biogeochemistry 106:137-156

Behrenfeld MJ, Falkowski PG (1997) A consumer's guide to phytoplankton primary productivity models. Limnol 
Oceanogr 42:1479-1491

Borum J (1996) Shallow waters and land/sea boundaries. In: Jørgensen BB, Richardson K (eds) Eutrophication in coastal marine ecosystems. American Geophysical Union, Washington, DC

Bouman H, Platt T, Sathyendranath S, Stuart V (2005) Dependence of light-saturated photosynthesis on temperature and community structure. Deep-Sea Res I 52: 1284-1299

Bouman HA, Nakane T, Oka K, Nakata K, Kurita K, Sathyendranath S, Platt T (2010) Environmental controls on phytoplankton production in coastal ecosystems: a case study from Tokyo Bay. Estuar Coast Shelf Sci 87: 63-72

Boynton WR, Kemp WM, Keefe CW (1982) A comparative analysis of nutrients and other factors influencing estuarine phytoplankton production. In: Kennedy VS (ed) Estuarine comparisons. Academic Press, New York, NY

Brush MJ, Brawley JW (2009) Adapting the light·biomass (BZI) models of phytoplankton primary production to shallow marine ecosystems. J Mar Syst 75:227-235

> Canion A, MacIntyre HL, Phipps S (2013) Short-term to seasonal variability in factors driving primary productivity in a shallow estuary: implications for modeling production. Estuar Coast Shelf Sci 131:224-234

> Cloern JE (2001) Our evolving conceptual model of the coastal eutrophication problem. Mar Ecol Prog Ser 210: 223-253

Cloern JE, Jassby AD (2010) Patterns and scales of phytoplankton variability in estuarine-coastal ecosystems. Estuaries Coasts 33:230-241

Cloern JE, Jassby AD (2012) Drivers of change in estuarinecoastal ecosystems: discoveries from 4 decades of study in San Francisco Bay. Rev Geophys 50, RG4001, doi:10. 1029/2012RG000397

> Cohen J (1992) Statistical power analysis. Curr Dir Psychol Sci 1:98-101

$>$ Cole BE, Cloern JE (1987) An empirical model for estimating phytoplankton productivity in estuaries. Mar Ecol Prog Ser 36:299-305

> Duarte CM, Conley DJ, Carstensen J, Sánchez-Camacho M (2009) Return to Neverland: Shifting baselines affect eutrophication restoration targets. Estuaries Coasts 32: 29-36

- Forget MH, Fuentes-Yaco C, Sathyendranath S, Platt T, Pommier J, Devred E (2007) Computation of primary production from remote sensing of ocean colour at the northwestern Atlantic C-SOLAS Lagrangian site. Mar Ecol Prog Ser 352:27-38

Gallegos CL (1992) Phytoplankton photosynthesis, productivity, and species composition in a eutrophic estuary: comparison of bloom and non-bloom assemblages. Mar Ecol Prog Ser 81:257-267

Gallegos CL (2012) Phytoplankton photosynthetic capacity in a shallow estuary: environmental correlates and interannual variation. Mar Ecol Prog Ser 463:23-37

Gallegos CL (2014) Long-term variations in primary production in a eutrophic sub-estuary. I. Seasonal and spatial patterns. Mar Ecol Prog Ser 502:53-67

> Gallegos CL, Bergstrom PW (2005) Effects of a Prorocentrum minimum bloom on light availability for and potential impacts on submersed aquatic vegetation in upper Chesapeake Bay. Harmful Algae 4:553-574

Gallegos CL, Jordan TE (2002) Impact of the Spring 2000 phytoplankton bloom in Chesapeake Bay on optical properties and light penetration in the Rhode River, Maryland. Estuaries 25:508-518

Gallegos CL, Correll DL, Pierce JW (1990) Modeling spectral diffuse attenuation, absorption, and scattering coefficients in a turbid estuary. Limnol Oceanogr 35: 1486-1502

Gallegos CL, Jordan TE, Correll DL (1997) Interannual variability in spring bloom timing and magnitude in the Rhode River, Maryland USA: observations and modeling. Mar Ecol Prog Ser 154:27-40

Gallegos CL, Jordan TE, Hedrick SS (2010) Long-term dynamics of phytoplankton in the Rhode River, Maryland (USA). Estuar Coast 33:471-484

> Gregg WW, Carder KL (1990) A simple spectral solar irradiance model for cloudless maritime atmospheres. Limnol Oceanogr 35:1657-1675

Harding LW Jr, Perry ES (1997) Long-term increase of phytoplankton biomass in Chesapeake Bay, 1950-1994. Mar Ecol Prog Ser 157:39-52

> Harding LW Jr, Mallonee ME, Perry ES (2002) Toward a predictive understanding of primary productivity in a temperate, partially stratified estuary. Estuar Coast Shelf Sci 55:437-463

Harding LW Jr, Batiuk RA, Fisher TR, Gallegos CL and others (2014) Scientific bases for numerical chlorophyll criteria in Chesapeake Bay. Estuar Coast 37:134-148

Harrison WG, Platt T (1980) Variations in assimilation number of coastal marine phytoplankton: effects of environmental co-variates. J Plankton Res 2:249-260

> Hayes JP, Shonkwiler JS (2006) Allometry, antilog transformations, and the perils of prediction on the original scale. Physiol Biochem Zool 79:665-674

> Hines AH, Haddon AM, Wiechert LA (1990) Guild structure and foraging impact of blue crabs and epibenthic fish in a subestuary of Chesapeake Bay. Mar Ecol Prog Ser 67: $105-126$

> Howarth RW, Billen G, Swaney D, Townsend A and others (1996) Regional nitrogen budgets and riverine N \& P fluxes for the drainages to the North Atlantic Ocean: natural and human influences. Biogeochemistry 35: 75-139

Jassby AD, Platt T (1976) Mathematical formulation of the relationship between photosynthesis and light for phytoplankton. Limnol Oceanogr 21:540-547

Jordan TE, Correll DL, Miklas J, Weller DE (1991a) Nutrients and chlorophyll at the interface of a watershed and an estuary. Limnol Oceanogr 36:251-267

> Jordan TE, Correll DL, Miklas J, Weller DE (1991b) Longterm trends in estuarine nutrients and chlorophyll, and short-term effects of variation in watershed discharge. Mar Ecol Prog Ser 75:121-132

Kimmel DG, Miller WD, Harding LW Jr, Houde ED, Roman MR (2009) Estuarine ecosystem response captured using a synoptic climatology. Estuar Coast 32:403-409

> Krause-Jensen D, Markager S, Dalsgaard T (2012) Benthic and pelagic primary production in different nutrient regimes. Estuar Coast 35:527-545

> Loftus ME, Subba Rao DV, Seliger HH (1972) Growth and dissipation of phytoplankton in Chesapeake Bay. I. Response to a large pulse of rainfall. Chesap Sci 13: 282-299

Malone TC, Crocker LH, Pike SE, Wendler BW (1988) Influences of river flow on the dynamics of phytoplankton production in a partially stratified estuary. Mar Ecol Prog Ser 48:235-249 
Najjar RG, Pyke CR, Adams MB, Breitburg D and others (2010) Potential climate-change impacts on the Chesapeake Bay. Estuar Coast Shelf Sci 86:1-20

Nixon SW (1995) Coastal marine eutrophication: a definition, social causes, and future concerns. Ophelia 41:199-219

Nixon SW (2009) Eutrophication and the macroscope. Hydrobiologia 629:5-19

Parker A, Kimmerer W, Lidström U (2012) Reevaluating the generality of an empirical model for light-limited primary production in the San Francisco Estuary. Estuar Coast 35: 930-942

Platt T, Sathyendranath S (1993) Estimators of primary production for interpretation of remotely sensed data on ocean color. J Geophys Res 98:14561-14576

> Platt T, Sathyendranath S, Ravindran P (1990) Primary production by phytoplankton: analytic solutions for daily rates per unit area of water surface. Proc Biol Sci 241: 101-111

Platt T, Sathyendranath $\mathrm{S}$, Forget $\mathrm{MH}$, White Iii GN and others (2008) Operational estimation of primary production at large geographical scales. Remote Sens Environ 112:3437-3448

Prasad M, Sapiano M, Anderson C, Long W, Murtugudde R (2010) Long-term variability of nutrients and chlorophyll in the Chesapeake Bay: a retrospective analysis, 19852008. Estuaries Coasts 33:1128-1143

Richardson K (1996) Carbon flow in the water column case study: the southern Kattegat. In: Jørgensen BB, Richardson K (eds) Eutrophication in coastal marine ecosystems, Vol 52. American Geophysical Union,

Editorial responsibility: Graham Savidge,

Portaferry, UK
Washington, DC

Richardson K, Jørgensen BB (1996) Eutrophication: definition, history and effects. In: Jorgensen BB, Richardson KR (eds) Eutrophication in coastal marine ecosystems, Vol 52. American Geophysical Union, Washington, DC

Schubel JR, Pritchard DW (1986) Responses of upper Chesapeake Bay to variations in discharge of the Susquehanna River. Estuaries 9:236-249

Seliger HH, Loftus ME (1974) Growth and dissipation of phytoplankton in Chesapeake Bay. II. A statistical analysis of phytoplankton standing crops in the Rhode and West Rivers and an adjacent section of the Chesapeake Bay. Chesap Sci 15:185-204

Smith VH (2007) Using primary productivity as an index of coastal eutrophication: the units of measurement matter. J Plankton Res 29:1-6

Southwick CH, Pine FW (1975) Abundance of submerged vascular vegetation in the Rhode River from 1966 to 1973. Chesap Sci 16:147-151

> Tyler MA, Seliger HH (1978) Annual subsurface transport of a red tide dinoflagellate to its bloom area: water circulation patterns and organism distributions in the Chesapeake Bay. Limnol Oceanogr 23:227-246

Wofsy SC (1983) A simple model to predict extinction coefficients and phytoplankton biomass in eutrophic waters. Limnol Oceanogr 28:1144-1155

Yoshiyama K, Sharp JH (2006) Phytoplankton response to nutrient enrichment in an urbanized estuary: apparent inhibition of primary production by overeutrophication. Limnol Oceanogr 51:424-434

Submitted: April 30, 2013; Accepted: December 31, 2013 Proofs received from author(s): March 19, 2014 